Bulletin of the Natural History Museum, 2015, 8: 21-45.

Received 02 Dec 2015; Accepted 18 Dec 2015.

doi: $10.5937 / \mathrm{bnhmb} 1508021 \mathrm{D}$

UDC: 069.51:561.4/.9(497.11); 561.4/.9:551.735(497.11-11)

Original scientific paper

\title{
A COLLECTION OF CARBONIFEROUS PLANTS OF VRŠKA ČUKA AT THE NATURAL HISTORY MUSEUM IN BELGRADE
}

\author{
DESA DJORDJEVIĆ MILUTINOVIĆ \\ Natural History Museum, Njegoševa 51, 11000 Belgrade, Serbia \\ e-mail: desadjm@nhmbeo.rs
}

The Natural History Museum in Belgrade possesses an extensive collection of Carboniferous fossil plants originating from the area of Vrška Čuka. The decision to show the collection came as a result of a number of specimens, the wellpreserved fossil material, and the fact that in Serbia there are very few localities with carboniferous flora.

The beginning of the research was impeded by the facts that material was never recorded in the Museum's inventory books, that there were no data about the chronology of the collection, and that the number of samples and their locations were not known. After several years of research, however, all the required data were obtained and the collection was finally completed and inventoried.

The genera of Cordaites, Pecopteris and Asterotheca prevail in the paleoflora of Vrška Čuka, but different seed ferns also appear in large numbers. There are also a few arborescent lycopsids and horsetails. Although the paleoflora originates from three localities that are close to each other, clear differences can be noted in the floristic composition, as well as the presence of certain taxa, particularly between the paleofloras of the streams Uzunov Potok and Surdžijski Potok.

Key words: Vrška Čuka, Carboniferous, paleoflora, Cordaites, Pecopteris. 


\section{INTRODUCTION}

The Collection encompasses over 430 specimens of Carboniferous fossil plants. The material originates from Vrška Čuka (Eastern Serbia), or to be more exact - from the localities of the streams Uzunov Potok, Bonin Potok and Surdžijski Potok. The specimens that make up the collection were gathered in 1948. and 1949.

The largest segment of the collection consists of the leaf impressions in coal shales. There are also some impressions of seeds, tree trunks and other plant organs, as well as imprints of fish scales and shells and a smaller amount of detritus of a plant origin which is difficult to identify.

In Serbia, there are only two localities with numerous and wellpreserved Carboniferous or Carboniferous-Permian flora: one is the broad area between the Mlava and Pek rivers, and the other is the paleoflora of Vrška Čuka, described in detail in this paper.

As the museum processed the collection, it was established that it was extremely rich in plant material, that the level of fossilization was good, and that the plants were easy to identify. To date, the collection has never been shown.

\section{MATERIAL AND METHODS}

The collection consists of 432 inventoried taxa, with inventory numbers from 1044 to 1338 (Inventory book of Paleobotany BEO 56:581, the Natural History Museum). These are mainly impressions or compressions of leaves, parts of tree trunks, or seeds in coal shales.

The numeration was performed according to the following principles (methods): given the fact that one piece of rock usually contains many overlapping fossil leaves, the inventory and marking of fossils was conducted using the following methodology: a piece of rock with plant imprints was marked by the main inventory number, while each plant fossil was marked using a subscript. For example, the piece of rock with the Inv. No. 1081 carries several different fossils, marked as Inv. No. 1081 Cordaites palmaeformis; Inv. No. $1081_{2}$ Samaropsis emarginata; Inv. No. $1081_{3}$ Eusphenopteris sp, etc. This method of marking was proven practical whenever there were multiple imprints on a single rock.

Given the fact that this collection was never recorded in the collection books or inventory books, its origin and the total number of specimens were not known until 2014, when a systematic research into and the processing of this collection began. The fact that notes (tags) with the 
localities and the collection dates were found in the boxes containing the fossil material significantly facilitated the work. This information made it clear that the material originated from Vrška Čuka, and that it was collected in June 1948 and 1949. Apart from this, the majority of practical data about the origin of the collection were obtained from the paper on the Carboniferous - Permian flora of Vrška Čuka (Pantić 1951).

The majority of the samples were identified during the research and a revision was performed concerning those that had already been identified, with the exception of Pteridospermatophyta, in which case the old terms were kept whenever they were found next to the fossils, where they had probably been placed by Nikola Pantić prior to $1951^{1}$ (e.g. in the case of Callipteris conferta Stern. the correct name is Autunia conferta Brong.). The remaining seed ferns were identified only as far as the genus. Moreover, all seed ferns needed a detailed and thorough revision. Cuticles were not preserved on the imprints of the leaves; identification was thus performed based on morphoanatomic characteristics which were possible to observe under the magnification of up to $40 \times(40-10)$. Although the imprints are in a rather good condition, some of them were still difficult to identify due in particular to poorly preserved specimens, for which it was impossible to determine whether they are leaves of Cordaites or the stems of Calamites.

The numbers in all the tables shown in this paper represent the number of specimens.

\section{RESULTS}

\section{Chronology of research}

The data found at the Museum are indicative of the fact that paleoflora was collected on Vrška Čuka in 1948 and 1949, on the banks of streams Uzunov Potok, Surdžijski Potok and Bonin Potok. On the basis of those data it was concluded that the fossils described by Pantić in his paper on the Lower Permian flora of Vrška Čuka (Pantić 1951) were actually a small part of the collection kept at the Museum. The data in Pantić's paper shows that items from the collection were gathered by geology students for the Geological Institute of the Serbian Academy of Sciences during their summer excursions in 1948 and 1949. Since the data and the localities presented in Pantić's paper and in the Museum Collection were congruous,

1 Nikola Pantić (1927-2002) - paleobotanist, member of the Serbian Academy of Sciences and Arts. 
the students of geology were named as the collectors of the Museum Collection. At that moment we knew who and when had collected the specimens; it was however still unknown how the Collection ended up at the Museum, because Pantic had said that it had been added to the collection of the Academy of Sciences. The most likely response to this question is that Nikola Pantić, who was volunteering at the Natural History Museum at that time, had brought the collection from the Academy of Sciences to the Museum in order to process it, after which the Collection remained there until today.

\section{COMPARISON OF THE PALEOFLORA PUBLISHED IN THE PAPER BY PANTIĆ IN 1951 AND THE SAMPLES IN THE MUSEUM COLLECTION}

Similarities: The type of fossils and fossilization, the sediment, the data concerning the collection and the localities.

Differences: The fossils whose drawings were presented by Pantic in his paper cannot be found in the collection, except for one recognized as Sphaenophyllum thonii (Pantić, 1951. pp. 129, Fig. 16). It is possible that Pantic had taken the fossils to draw them, as part of his work on the paper, and that he had never returned them. In his paper Pantić also fails to mention the existence of a single Lepidodendrales, not even Stigmaria, of which there are several in the collection. He also mentions the fossil which he believes to be Coniferae, while in the Museum Collection, however, there are no imprints similar to conifers (except for Inv. No. $1208_{2}$ Lepidodendron vel Coniferales). The author assumes that Pantić only presented a small segment of the fossils from the Museum Collection, and that the samples that appear in the drawings were never returned to the Collection.

Until 2015 the number of fossils in the Collection was unknown because the boxes with the paleoflora had been kept in different locations. Most of them were in the Paleobotanical Collection. Some of the boxes were also preserved in other geological collections, while approximately ten of the most beautiful samples were found among the exhibition material.

To date, this collection has never been presented in its entirety. A part of the Collection was processed in a graduation paper (Stevanović 1996), while another, smaller part was subjected to a revision by our colleague Yanaki Tenchov (Bulgarian Academy of Sciences) in 2010. No sooner than in 2014, however, was the complete material gathered in a single location, where the objects were identified, inventoried and revised. It was only then that it became clear that the collection was much bigger and far more significant than anyone had thought. 


\section{The matter of age}

The age of the flora has not been determined with certainty. Pantic (Pantić 1951) believed that flora belonged to the Upper Permian age, only to later conclude, having reviewed the material one more time (Pantić 1969), that it was partly of the Stephanian and partly of the early Permian age. Škerlj and Milovanović (in Veselinović et al. 1975) consider it to be typical Stephanien flora. However, none of the authors mention that in these localities there were arborescent (tree-like) lycopsids, which were found in the Museum Collection (primarily Stigmaria). Here, the Stephanien-Permian flora which was found in the wide area between the Mlava and Pek rivers (eastern Serbia) should also be mentioned. (Pantić 1952, Djordjević Milutinović 2010, 2013). From the taxonomical standpoint, this flora is not similar to the paleoflora of Vrška Čuka; Linopteris and Alethopteris prevail, while Cordaites are found in small numbers and arborescent lycopsids are only represented by several samples of a Sigillaria tree trunk.

Note: It should also be mentioned that among the plant fossils from the locality of Surdžijski Potok there is also one well preserved large sample of the leaf Zamites sp. Inv. No. 1295-1300 (a genus characteristic of the Mesozoic), which does not fit into the composition of the Carboniferous flora. How this fossil appeared in the Collection, or whether this fossil was truly found in Surdžijski Potok - which is almost impossible - is unknown. Given the fact that Liassic layers were also found on Vrška Čuka, the sediments being of a similar structure, it is possible that one of the students had temporarily placed the specimen among the Carboniferous fossils, where it had remained.

\section{The description of the localities and the material}

The material collected on Vrška Čuka was brought in from three sites (Fig. 1-2,): the streams of Uzunov Potok, Bonin Potok and Surdžijski Potok. It was collected during a minimum of two seasons, in 1948 and 1949. The fossiliferous sites with paleoflora are located south-westwards from the Avramica village. The Avramička Reka, the right tributary of Beli Timok river, flows through the mining settlement of Avramica (the anthracite mine).

Three streams, namely Surdžijski Potok, Bonin Potok and Uzunov Potok are not written in the official geographical and geological maps In 2015, field research in the area of Vrška Čuka was renewed, but newly collected paleoflora specimens do not correspond to those from the Collection either by the type of fossilization or by the number of specimens. The largest parts of the streams are not accessible today, 
DJORDJEVIĆ MiLUTINOVIĆ, D.: CARBONIFEROUS PLANTS OF VRŠKA ČUKA

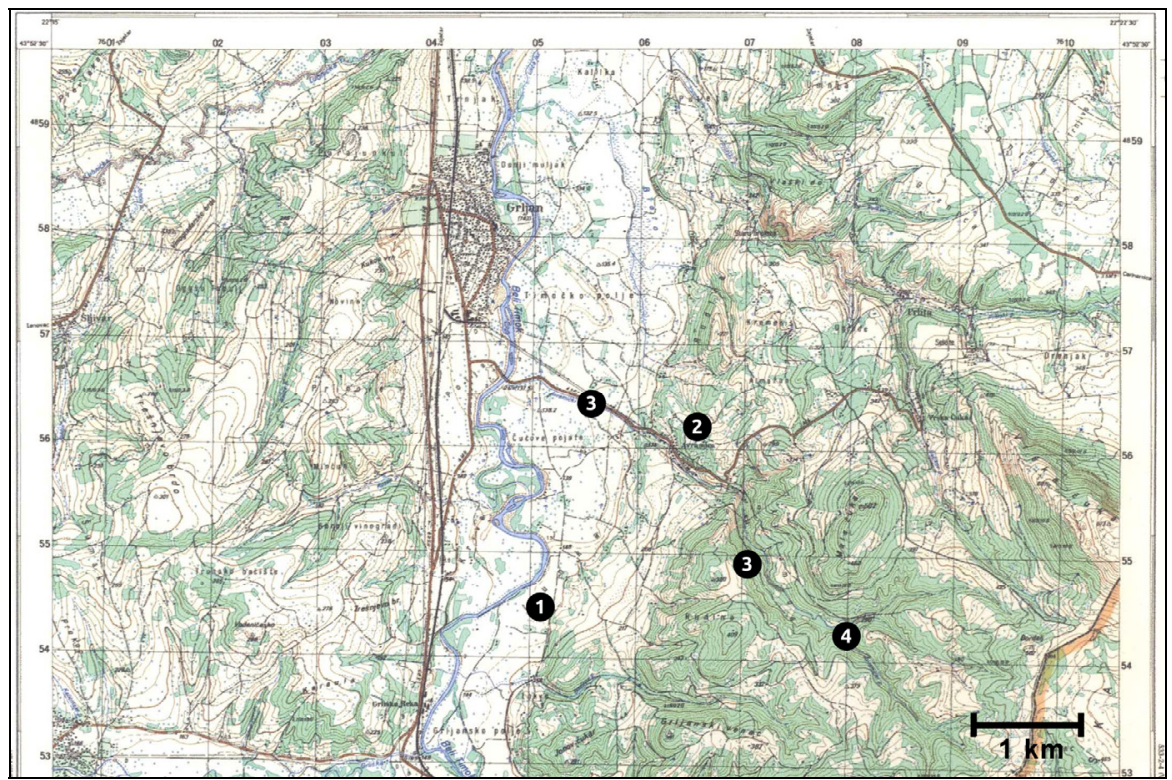

Fig. 1. - Topographic map shows the location of Beli Timok river (1), mining settlement Avramica (2), Avramička Reka river (3), confluence of the streams and Avramička Reka river (4).

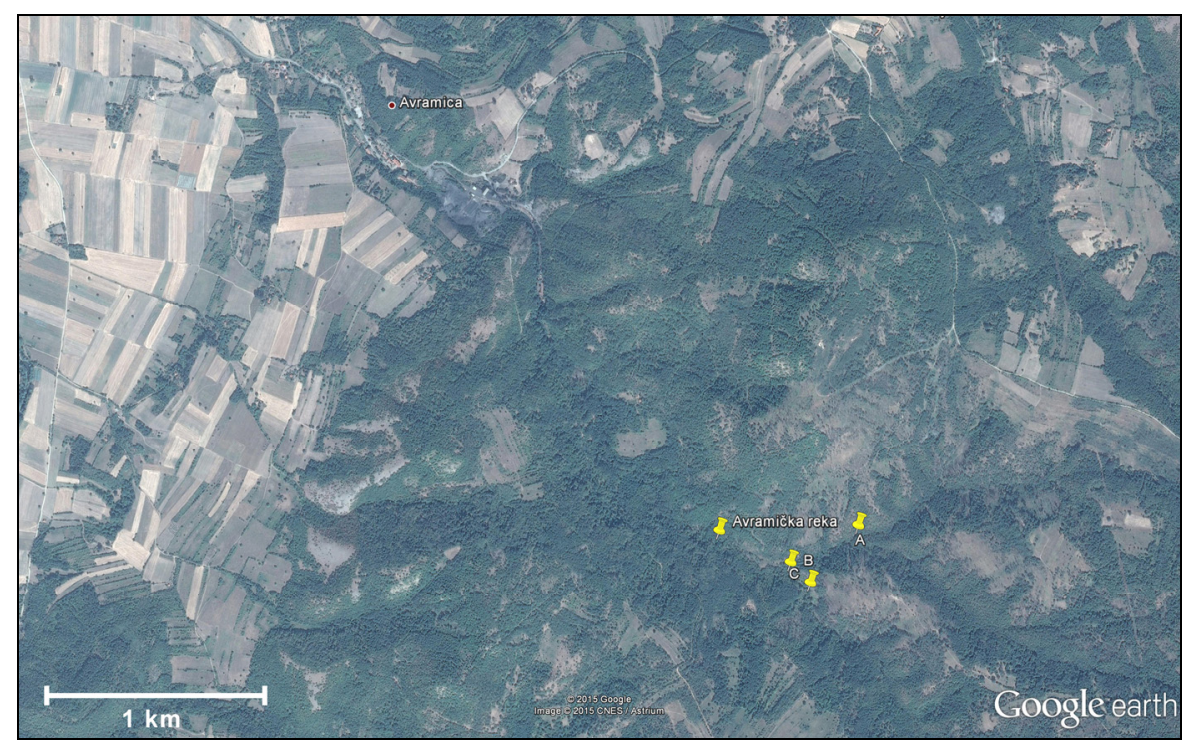

Fig. 2. - Position of the Avramička Reka river and streams (satellite map): A - Uzunov Potok; B - Bonin Potok; C-Surdžijski Potok.

because, in their middle course, the streams are filled with stones and flattened tree trunks and covered by vegetation. The newcollected paleoflora was found in vicinity of streams confluence with Avramička Reka river: Uzunov Potok 


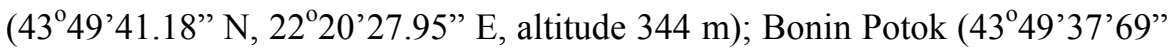

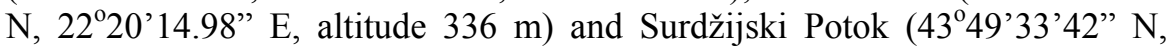
$22^{\circ} 20^{\prime} 19.40$ " E, altitude $312 \mathrm{~m}$ ). Based on the description of localities done by Pantic $(1951,1969)$, the author of this paper assumes that the paleoflora specimens from the Museum's Collection were gathered somewhere else, probably upstream, near by the border between Serbia and Bulgaria.

\section{UZUNOV POTOK}

Table 1. - Collection book of the Uzunov Potok

\begin{tabular}{lc}
\hline Date of collection & Number of specimens \\
\hline 11 VII 1948 & 71 \\
22 VII 1949 & 165 \\
Total number of samples & 236 \\
\hline
\end{tabular}

Fossils from the Uzunov Potok locality

Table 1.1. - Cordaitales

\begin{tabular}{|c|c|c|}
\hline Cordaitales & Inventory Number 56:581 - & Total \\
\hline Cordaites borassifolius & $\begin{array}{l}1056 ; 1066 ; 1067_{3} ; 1072 ; 1103 ; 1113 ; \\
1262_{1} ; 279_{1} ; 1286_{2}\end{array}$ & 9 \\
\hline Cordaites palmaeformis & $\begin{array}{l}1045_{2} ; 1046 ; 1048 ; 1049 ; 1050_{1} ; 1051 ; \\
1053_{2} ; 1055_{4} ; 1060_{2} ; 1061 ; 1064 ; 1065 ; \\
1067_{1} ; 1068 ; 1069_{2} ; 1071_{1} ; 1076_{1} ; 1077 \\
1081_{1} ; 1083 ; 1085_{4} ; 1088_{2} ; 1090 ; 1093 ; \\
1101_{1} ; 1102_{1} ; 1118 ; 1119_{2} ; 1215_{2} ; 1223_{2} ; \\
1242_{2} ; 1249_{1} ; 1277_{1}\end{array}$ & 33 \\
\hline ?Cordaites palmaeformis & $1057_{1} ; 1062_{2} ; 1063_{2} ; 1075$ & 4 \\
\hline $\begin{array}{l}\text { Cordaites cf. } \\
\text { palmaeformis }\end{array}$ & 1096 & 1 \\
\hline Cordaites principalis & $\begin{array}{l}1044 ; 1047_{1} ; 1052 ; 1053_{1} ; 1055_{1} ; 1057_{2} ; \\
1058 ; 1059 ; 1060_{1} ; 1062_{1} ; 1063_{3} ; 1070 ; \\
1073_{1} ; 1074 ; 1084 ; 1085_{2} ; 1086 ; 1087 ; \\
1088_{1} ; 1089 ; 1091 ; 1092 ; 1094 ; 1095_{1} ; \\
1099_{2} ; 1101_{4} ; 1102_{2} ; 1110_{1} ; 1114_{2} ; 1119_{3} ; \\
1249 ; 1260 ; 1266 ; 1278 ; 1292\end{array}$ & 35 \\
\hline Cordaites cf. principalis & $1080 ; 1112$ & 2 \\
\hline ?Cordaites principalis & $1045_{1} ; 1054_{1} ; 1078 ; 1079_{1} ; 1082_{1}$ & 5 \\
\hline Cordaites sp. & $1120_{1} ; 1271 ; 1272_{1} ; 1281_{1} ; 1293_{2}$ & 5 \\
\hline Cordaites spp. & $1227 ; 1243_{2} ; 1246_{2} ; 1254$ & 4 \\
\hline ?Cordaites sp. & $1117_{2} ; 1248_{2}$ & 2 \\
\hline Cyperittes sp. & $1102_{3}$ & 1 \\
\hline
\end{tabular}


Table 1.2. - Seed ferns

\begin{tabular}{llc}
\hline Pteridospermatophyta & Inventory Number 56:581 - & Total \\
\hline Alethopteris $\mathrm{sp}$. & $1244 ; 1289_{2}$ & 2 \\
?Alethopteris $\mathrm{sp}$ & 1275 & 1 \\
Aphlebia sp. & $1085_{1}$ & 1 \\
?Aphlebia sp. & $1063_{1}$ & 1 \\
?Calipteris conferta & 1225 & 1 \\
?Eusphenopteris $\mathrm{sp}$. & $1079_{2} ; 1081_{3}$ & 2 \\
Linopteris sp. & $1108 ; 1121$ & 2 \\
Mariopteris muricata & $1245_{1}$ & 1 \\
?Mariopteris sp. & $1101_{3} ; 1076_{2}$ & 2 \\
Neuropteris $\mathrm{sp}$. & $1232 ; 1235 ; 1273$ & 3 \\
?Neuropteris $\mathrm{sp}$. & $1055_{3} ; 1230 ; 1239 ; 1255 ; 1256 ; 1262_{2} ; 1293_{1}$ & 7 \\
Odontopteris minor & $1286_{1} ; 1287$ & 2 \\
Odontopteris $\mathrm{sp}$ & $1279_{4}$ & 1 \\
?Odontopteris $\mathrm{sp}$. & $1095_{2} ; 1120_{2}$ & 2 \\
Sphenopteris $\mathrm{sp}$. & $1289_{1}$ & 1 \\
?Sphenopteris $\mathrm{sp}$. & $1100_{1} ; 1116$ & 2 \\
\hline
\end{tabular}

Table 1.3. - Tree ferns

\begin{tabular}{llc}
\hline Marattiales & Inventory Number $56: 581-$ & Total \\
\hline $\begin{array}{l}\text { Asterotheca } \\
\text { arborescens }\end{array}$ & $1106_{4} ; 1240$ & 2 \\
Asterotheca sp. & $1104 ; 1105 ; 1114_{1} ; 1233 ; 1236 ; 1252 ; 1267 ;$ & 8 \\
& $1290_{3}$ & \\
? Asterotheca sp. & $1082_{2} ; 1085_{3} ; 1110_{2} ; 1111$ & 4 \\
Asterotheca sp. 1 & $1117_{1} ; 1218 ; 1221 ; 1222 ; 1263 ; 1264 ; 1276$ & 7 \\
Caulopteris sp & $1054_{3}$ & 1 \\
Pecopteris bucklandii & $1073_{3}$ & 1 \\
Pecopteris sp. & $1047_{1} ; 1050_{2} ; 1054_{2} ; 1055_{2} ; 1071_{2} ; 1101_{2} ;$ & 34 \\
& $1109_{2} ; 1119_{1} ; 1214_{2} ; 1217 ; 1219 ; 1220 ;$ & \\
& $1223_{3} ; 1224 ; 1226 ; 1228 ; 1237 ; 1242_{1} ;$ & \\
& $1243_{1} ; 1246_{1} ; 1247 ; 1248_{1} ; 1251 ; 1253 ;$ & \\
& $1257 ; 1258 ; 1259 ; 1250 ; 1274_{2} ; 1279_{2} ;$ & \\
Pecopteris sp. 1 & $1283 ; 1284 ; 1285 ; 1294$ & 2 \\
Pecopteris sp. 2 & $1277_{2} ; 1282$ & 2 \\
?Pecopteris sp. & $1290_{1} ; 1292_{2}$ & \\
& $1067_{2} ; 1069_{1} ; 1095_{3} ; 1106_{1} ; 1107_{2} ; 1241_{3} ;$ & 8 \\
Pecopteris / & $1249_{3} ; 1272_{2}$ & 1 \\
Asterotheca sp. 1 & $1279_{3}$ & \\
\hline
\end{tabular}


Table 1.4. - Horsetails

\begin{tabular}{llc}
\hline Equisetophyta & Inventory Number 56:581 - & Total \\
\hline Annularia stellata & $1293_{3}$ & 1 \\
Annularia stellata folium & $1241_{1}$ & 1 \\
Annularia stellata truncum & $1241_{2}$ & 1 \\
Calamites $\mathrm{sp}$ & $1274_{1} ; 1290_{2}$ & 2 \\
?Calamites $\mathrm{sp}$ & $1288_{2}$ & 1 \\
\hline
\end{tabular}

Table 1.5. - Arboresent lycopsids

\begin{tabular}{llc}
\hline Lepidodendrales & Inventory Number 56:581 - & Total \\
\hline ?Asolanus sp. & $1097 ; 1098 ; 1099 ; 1115$ & 4 \\
?Lepidophyllum $\mathrm{sp}$. & $1245_{3}$ & 1 \\
?Stigmaria sp. & $1281_{2}$ & 1 \\
\hline
\end{tabular}

Table 1.6. - Seeds

\begin{tabular}{llc}
\hline Semen & Inventory Number 56:581 - & Total \\
\hline Samaropsis fluitans & $1106_{2} ; 1109_{2}$ & 2 \\
Samaropsis emarginata & $1106_{3} ; 1107_{1}$ & 2 \\
Samaropsis cf. fluitans & $1073_{2}$ & 1 \\
Samaropsis sp. & $1081_{2}$ & 1 \\
$\begin{array}{l}\text { Samaropsis aut Cordaitanthus } \\
\text { pseudofluitans }\end{array}$ & 1291 & 1 \\
$\begin{array}{l}\text { Samaropsis sp. } \\
\text { vel Corynocarpus sp. }\end{array}$ & $1288_{1}$ & 1 \\
?Semen & $1100_{2}$ & 1 \\
\hline
\end{tabular}

Table 1.7. - Fossils of uncertan taxonomic affilation

\begin{tabular}{llc}
\hline Indefinite & Inventory Number 56:581 - & Total \\
\hline Asterotheca vel Alethopteris & 1216 & 1 \\
Pecopteris volkmannii vel & 1229 & 1 \\
Lobatopteris miltoni & & \\
?Pecopteris vel ?Alethopteris & $1265 ; 1266_{2}$ & 2 \\
?Pecopteris vel Neuropteris & $1231 ; 1261 ; 1266_{2}$ & 3 \\
\hline
\end{tabular}

Table 1.8. - The rest of fossils

\begin{tabular}{llc}
\hline Et alii & Inventory Number 56:581 - & Total \\
\hline Pinulas indet. & $1234_{2}$ & 1 \\
Semen vel fructus & $1245_{2}$ & 1 \\
?Strobus & $1216_{2} ; 1241$ & 2 \\
Truncus petrefactum & 1280 & 1 \\
?Truncus & $10913 ; 10993$ & 2 \\
Truncus partes & $1234_{1} ; 1238 ; 1268 ; 1269 ; 1270$ & 5 \\
\hline
\end{tabular}




\section{SURDŽIJSKI POTOK}

Table 2. - Collection book of the Surdžijski potok locality

\begin{tabular}{lc}
\hline Date of collection & Number of specimens \\
\hline 11 VII 1948 & 22 \\
6 VII 1949 & 43 \\
Mixed material from 1948. and 1949. & 116 \\
\hline Total & 181 \\
\hline
\end{tabular}

Fossils from the Surdžijski potok locality

Table 2.1. - Cordaitales

\begin{tabular}{llc}
\hline Genus Cordaites & Inventory Number 56:581 - & Total \\
\hline ?Cordaianthus sp. & $1148_{2}$ & 1 \\
Cordaites borassifolius & $1150_{2} ; 1183_{2} ; 1185$ & 3 \\
Cordaites palmaeformis & $1183_{3} ; 1184 ; 1152_{2} ; 1155 ; 1157_{2} ; 1161 ;$ & 13 \\
& $1163 ; 1164 ; 1167_{1} ; 1326_{2} ; 1329_{2} ; 1330_{2} ;$ & \\
& $1331_{3}$ & 8 \\
Cordaites principalis & $1145 ; 1154 ; 1156 ; 1157_{3} ; 1158 ; 1162 ;$ & \\
& $1186_{1} ; 1214_{1}$ \\
Cordaites sp. & $1141 ; 1142 ; 1144 ; 1159 ; 1160 ; 1172 ;$ & 14 \\
& $1186_{3} ; 1187 ; 1188_{1} ; 1190_{2} ; 1191 ; 1194_{2} ;$ & \\
Cordaites spp. & $1195_{2} ; 1200_{2}$ & 2 \\
?Cordaites sp. & $1140 ; 1146$ & 1 \\
\hline
\end{tabular}

Table 2.2. - Seed ferns

\begin{tabular}{llc}
\hline Pteridospermatophyta & Inventory Number 56:581 - & Total \\
\hline Alliopteris tennuissima & $1322 ; 1323_{1}$ & 2 \\
Callipteridium zeilleri & $1148_{1} ; 1149 ; 1150_{3} ; 1151_{1}$ & 4 \\
Callipterits conferta & $1335 ; 1336 ; 1337_{1}$ & 3 \\
Linopteris sp. & $1152_{1} ; 1190_{1} ; 1206 ; 1207$ & 4 \\
?Linopteris germari & $1157_{1} ; 1193_{1}$ & 2 \\
Lonchopteris $\mathrm{sp}$. & 1147 & 1 \\
? Lonchopteris $\mathrm{sp}$. & $1167_{2}$ & 1 \\
Neuropteris $\mathrm{sp}$. & $1151_{2} ; 1209_{3} ; 1304_{1} ; 1305 ; 1306_{1} ; 1307 ;$ & 19 \\
& $1309 ; 1311 ; 1312_{2} ; 1313 ; 1314 ; 1315 ;$ & \\
& $1316 ; 1317 ; 1318 ; 1319 ; 1320 ; 1321 ;$ & \\
Neuropteris $\mathrm{sp} .1$ & $1331_{4}$ & 1 \\
Neuropteris $\mathrm{sp} .2$ & 1302 & 3 \\
?Odontopteris $\mathrm{sp}$. & $1303 ; 1308_{1} ; 1310$ & 1 \\
Palmatopteris $\mathrm{sp}$ & $1157_{5}$ & 1 \\
Sphenopteris $\mathrm{sp}$. & $1312_{1}$ & 1 \\
\hline
\end{tabular}


Table 2.3. - Tree ferns

\begin{tabular}{llc}
\hline Marttiales & Inventory Number 56:581 - & Total \\
\hline Asterotheca arborescens & $1213_{3}$ & 1 \\
Asterotheca sp & $1188_{2} ; 1194_{1} ; 1195_{1} ; 1198 ; 1323_{2} ; 1325_{2}$ & 6 \\
Pecopteris arborescens & $1200_{1}$ & 1 \\
Pecopteris cf. cyathea & 1199 & 1 \\
Pecopteris sp. & $1195_{3} ; 1196 ; 1198 ; 1312_{3} ; 1323_{3} ; 1324 ;$ & 8 \\
& $1325_{1} ; 1337_{2}$ & \\
?Pecopteris sp. & $1157_{4} ; 1193_{2} ; 1214_{2}$ & 3 \\
\hline
\end{tabular}

Table 2.4. - Horsetails

\begin{tabular}{llc}
\hline Equisetophyta & Inventory Number 56:581 - & Total \\
\hline Annularia sphenophylloides & $1151_{3} ; 1326_{1} ; 1327 ; 1328_{1} ; 1330_{1} ;$ & 9 \\
& $1331_{1} ; 1332 ; 1333 ; 1334$ & \\
Calamites sp. & $1169 ; 1170 ; 1171 ; 1182 ; 1213_{2}$ & 5 \\
?Calamites sp. & $1304_{2}$ & 1 \\
Sphenophyllum thonii & 1213 & 1 \\
\hline
\end{tabular}

Table 2.5. - Arboresent lycopsids

\begin{tabular}{llc}
\hline Lepidodendrales & Inventory Number 56:581 - & Total \\
\hline Lepidodendron rami cum foliis & 1203 & 1 \\
Stigmaria ficoides & $1173 ; 1174 ; 1175 ; 1176 ; 1177 ;$ & 9 \\
& $11781179 ; 1180 ; 1181$ & \\
Stigmaria cf ficoides & $1201 ; 1202 ; 1203$ & 3 \\
Stigmaria sp. & $1208 ; 1210 ; 1211$ & 3 \\
Stigmaria sp. radicle & 1203 & 1 \\
Lepidodendron sp. & $1209 ; 1210 ; 1211 ; 1212$ & 4 \\
?Lepidophyllum sp. & $1209_{4} ; 1210_{3} ; 1212_{2}$ & 3 \\
?Lepidostrobus & $1148_{2}$ & 1 \\
\hline
\end{tabular}

Table 2.6. - Seeds

\begin{tabular}{llc}
\hline Semen & Inventory Number 56:581 - & Total \\
\hline Rhabdocarpus sp. & 1204 & 1 \\
?Samaropsis sp. & 1205 & 1 \\
\hline
\end{tabular}


32 DJORDJEVIĆ MilutinOVIĆ, D.: CARBONIFEROUS PLANTS OF VRŠKA ČUKA

Table 2.7. - Fossils of uncertan taxonomic affilation

\begin{tabular}{llc}
\hline Indefinite & $\begin{array}{l}\text { Inventory Number } \\
56: 581-\end{array}$ & Total \\
\hline $\begin{array}{l}\text { Cordaites palmaeformis vel } \\
\text { Calamites cistii }\end{array}$ & $1165 ; 1166$ & 2 \\
$\begin{array}{l}\text { Cordaites principalis vel Calamites sp. } \\
\text { Cordaites sp. vel Calamites cf. cistii }\end{array}$ & 1139 & 1 \\
?Cordaites vel Calamites & $1153 ;$ & 1 \\
Lepidodendron vel Coniferales rami cum & $1328 ; 1331$ & 2 \\
foliis & $1208_{2}$ & 1 \\
Neuropteris sp. 3 vel Cyclopteris sp. & $1329_{1}$ & 1 \\
?Cycadophyta & 1197 & 1 \\
\hline
\end{tabular}

Table 2.8. - The rest of fossils

\begin{tabular}{llc}
\hline Et alii & Inventory Number 56:581 - & Total \\
\hline Arborum cortices & $1186_{2}$ & 1 \\
Detritus & $1188_{3} ; 1192_{2} ; 1195_{4} ; 1199_{2} ; 1200_{3}$ & 5 \\
Lignum & $1137 ; 1138 ; 1143$ & 3 \\
?Polipodiaceae & 1192 & 1 \\
Truncus & $1189 ; 1306_{2} ; 1308_{2}$ & 3 \\
Squamis & $1192_{3} ; 1306_{3}$ & 2 \\
?Squamis & $1190_{3}$ & 1 \\
Squamis vel strobilus & $1183_{3}$ & 1 \\
\hline
\end{tabular}

\section{BONIN POTOK}

Table 3. - Collection book of the Bonin potok locality

\begin{tabular}{cc}
\hline Date of collection & Number of specimens \\
\hline 23 VII 1949 & 22 \\
\hline
\end{tabular}

Fossils from the Bonin Potok locality

Table 3.1. - Cordaitales

\begin{tabular}{llc}
\hline Ordo Cordaites & Inventory Number 56:581 - & Total \\
\hline Cordaites borassifolius & $1129_{2} ; 1131$ & 2 \\
Cordaites microstachys & $1122_{1} ; 1123 ; 1124_{3}$ & 3 \\
Cordaites palmaeformis & $1122_{2} ; 1124_{2} ; 1125_{2} ; 1128 ; 1129_{1} ; 1133_{1}$ & 6 \\
Cordaites principalis & $1125 ; 1126 ; 1127 ; 1130$ & 4 \\
Cordaites sp & $1132_{1} ; 1135$ & 2 \\
\hline
\end{tabular}


Table 3.2. - Seed ferns

\begin{tabular}{llc}
\hline Pteridospermatophyta & Inventory Number 56:581 - & Total \\
\hline ?Sphenopteris $\mathrm{sp}$. & $1132_{2} ; 1135$ & 2 \\
Odontopteris $\mathrm{sp}$. & 1136 & 1 \\
?Odontopteris $\mathrm{sp}$ & $1133_{2}$ & 1 \\
\hline
\end{tabular}

Table 3.3. - Fossils of uncertan taxonomic affilation

\begin{tabular}{l|l|c}
\hline Indefinite & Inventory Number 56:581 - & Total \\
\hline $\begin{array}{l}\text { Callipteridium zeilleri vel } \\
\text { ?Sphenopteris } \text { sp. }\end{array}$ & 1134 & 1 \\
\hline
\end{tabular}

\section{DISCUSSION}

\section{The analysis of the presence of fossil plants}

Cordaites are the most numerous and they more or less dominate in all three localities. Ferns are numerous as well, and the fact that they are not present at Bonin Potok can be ascribed to a small number of collected samples rather than the real difference in the floristic composition in comparison with the other two localities.

It is indicative that arborescent lycopsids were identified with certainty only in Surdžijski Potok, which corresponds with the opinion of N. Pantić (Pantić 1969), according to whom the flora of this area is somewhat older than that of Uzunov Potok. It is, however, also possible that the differences in the habitats are simply reflected in the composition of the flora.

Seed ferns are also quite numerous. Although they must be revised, we can say with certainty that they are diverse and that a large number of morphogenera are present, which can mean that, together with cordaites, they belonged to the climax vegetation.

There are very few calamites, and they were found mainly in Surdžijski Potok, whose paleofloristic composition (calamites, lycopsids, detritus, fish scales) indicates swampy habitats in the vicinity of the banks.

\section{PTERIDOSPERMATOPHYTA}

Seed ferns are numerous, morphologically diverse and represented by several morphotypes (Tab. 4). What was found was mostly individual pinnulas, while parts of fronds were encountered very rarely. There are 


\section{DJORDJEVIĆ MILUTINOVIĆ, D.: CARBONIFEROUS PLANTS OF VRŠKA ČUKA}

very few Alethopteris and Linopteris, which were found in large numbers in other Upper Carboniferous localities, such as the area between the Mlava and Pek rivers (the Stephanien, Eastern Serbia) (Pantić 1952, Djordjević Milutinović 2013).

Table 4. - Seed ferns genera from Vrška Čuka localities in the Museum Collection.

\begin{tabular}{lccc}
\hline & Uzunov potok & Bonin potok & Surdzijski potok \\
\hline Alethopteris & 3 & & \\
Aphlebia & 2 & & 2 \\
Alliopteris & & 4 \\
Callipteridium & & 3 \\
Callipteris & & \\
Eusphenopteris & 2 & & 6 \\
Linopteris & 2 & 2 & 2 \\
Lonchopteris & & & \\
Mariopteris & 3 & 2 & 1 \\
Neuropteris & 10 & & 1 \\
Odontopteris & 3 & & 1 \\
Palmatopteris & & & \\
Sphenopteris & 3 & & \\
\hline
\end{tabular}

\section{CORDAITES}

Cordaites are present in large numbers. There are four species. The leaves are fragmented and not a single whole leaf has been found. On some of the pieces, leaves are found in the mass, lying one over another; these samples were impossible to identify exactly and they were marked as Cordaites species plural, Cordaites spp. In some of the cases it was impossible to determine the species to which they belong because of bad fossilization, and they were thus identified as Cordaites species, Cordaites sp. (Tab. 5)

Table 5.-Cordaites species from Vrška Čuka localities in the Museum Collection.

\begin{tabular}{lccc}
\hline Taxon & Uzunov potok & Bonin potok & Surdzijski potok \\
\hline C. borassifolius & 9 & 2 & 17 \\
C. microstachys & & 3 & \\
C. palmaeformis & 38 & 6 & 13 \\
C. principalis & 42 & 4 & 8 \\
Cordaites sp. & 11 & 2 & 17 \\
Cordaites spp. & 4 & & 2 \\
\hline
\end{tabular}




\section{TREE FERNS (ORDO MARATTIALES)}

As regards tree ferns, the dominant ones are morphogenera Pecopteris and Asterotheca, due to the fact that they are practically fertile and sterile pinnulas, sometimes of the same ferns, and that on some samples they can be seen on the same frond, on pinnule with sporangia as well as on pinnule without sporangia (Tab. 6). Here, they are viewed as one group of Pecopteris/Asterotheca.

Table 6. - Tree ferns from Vrška Čuka localities in the Museum Collection.

\begin{tabular}{lccc}
\hline Taxon & Uzunov potok & Bonin potok & Surdžijski potok \\
\hline Asterotheca et Pecopteris & 69 & 21 \\
Marattiales indet. & 3 & \\
\hline
\end{tabular}

\section{EQUISETOPHYTA}

As regards calamites, mainly tree trunks and branches with leaves were found, most of them in Surdžijski Potok (Tab. 7).

Table 7. - Horsetails from Vrška Čuka localities in the Museum Collection.

\begin{tabular}{|c|c|c|c|}
\hline Taxon & Uzunov potok & Bonin potok & Surdžijski potok \\
\hline Anularia sphenophylloides & & & 10 \\
\hline Annularia stellata & 3 & & \\
\hline Calamites sp. & 3 & & 6 \\
\hline Sphenophyllum thonii & & & 1 \\
\hline
\end{tabular}

\section{LEPIDODENDRALES}

Arborescent lycopsids were found in Surdžijski Potok. The majority of the collected fossils are Stigmaria sp. (Tab. 8)

Table 8. - Arborescent lycopsidas from Vrška Čuka localities in the Museum Collection.

\begin{tabular}{|c|c|c|c|}
\hline Taxon & Uzunov potok & Bonin potok & Surdžijski potok \\
\hline Lepidodendron & & & 5 \\
\hline Stigmaria & $?$ & & 16 \\
\hline ?Lepidophyllum & $?$ & & 3 \\
\hline ?Lepidostrobus & & & 1 \\
\hline
\end{tabular}




\section{Comparative analysis of paleoflora from Vrška Čuka}

All the groups of plants that are characteristic of the Upper Carboniferous are present in the Mueseum Collection of Vrška Čuka: gymnosperms (Cordaites), seed ferns (Sphaenopteris, Neuropteris, Odontopteris), tree ferns (Pecopteris, Asterotheca), arborescent lycopsids (Stigmaria, Lepidodendron), and calamites (Annularia, Calamites, Sphaenophyllum) (Tab. 9, Fig. 3-4).

Table 9. - The quantitative presence of certain groups of plants, characteristic for the Upper Carboniferous.

Taxon

Uzunov potok Bonin potok Surdžijski potok

Cordaites

Pecopteris /

Asterotheca

Lepidodendrales

Pteridospermatophyta

Equisetophyta
100

69

17

41

21

24

27

4

44

6

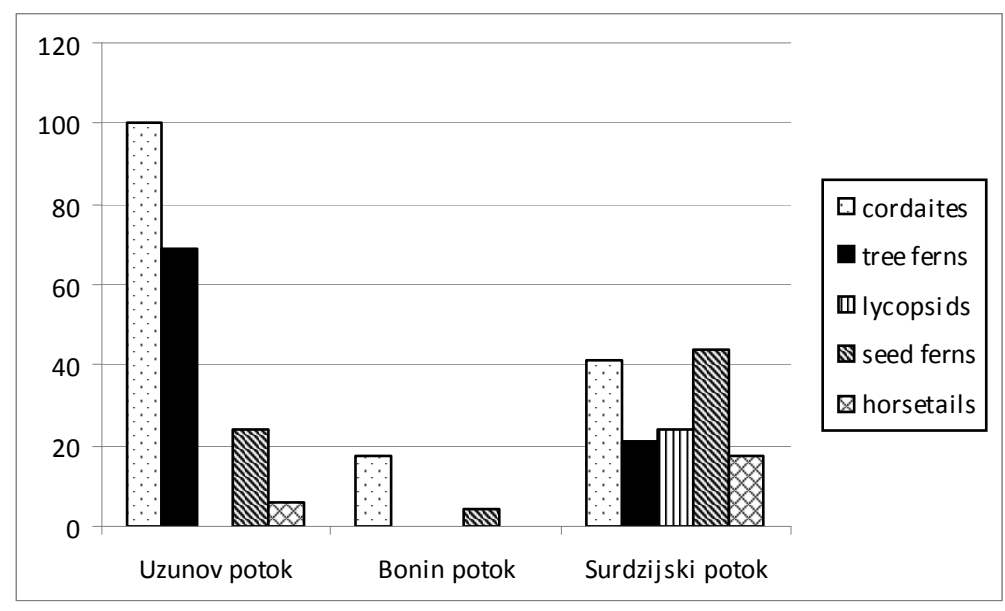

Fig. 3. - Presence of the plant groups, shown through the number of specimens, in all three localities (streams), Uzunov Potok, Bonin Potok and Surdžijski Potok. 


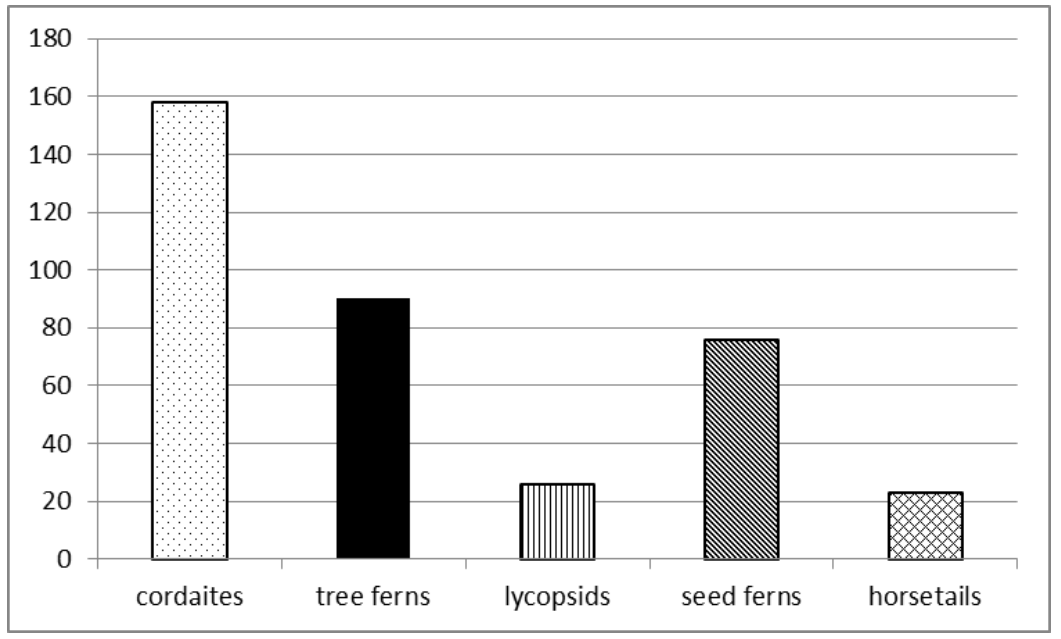

Fig. 4. - Total presence of taxa in the area of Vrška Čuka - synthesis of all three localities.

\section{CONCLUSION}

On the basis of the presented data from the Collection it can be concluded that paleoflora of Uzunov Potok and Surdžijski Potok show clear differences in their composition - not so much from the taxonomical point of view but rather from the point of view of the presence of certain taxa. Uzunov Potok is dominated by cordaities and ferns, seed ferns and calamites are present infrequently, whereas lycopsids are completely absent. In Surdžijski Potok all the classes of plants are, however, equally represented, including arborescent lycopsids. Taphocenosis in Uzunov Potok indicates the presence of a forest community which was dominated by cordaites and tree ferns, whereas the elements of swamp were found in small numbers - as calamites - or none at all (arborescent lycopsids).

It is possible that this community was growing away from the deposition environment, while the community of Surdžijski Potok most probably represented a polydominant forest in which cordaites, seed ferns, tree ferns and swamp elements such are horsetails and lycopsids were equally present. Such a community could have been growing in the vicinity of the deposition environment, on the swampy mud banks. The findings of detritus in the form of remnants of tree trunks and fish scales, which were also found in Surdžijski Potok and which indicate that the fossils originate from the vicinity of the deposition environment, are also worth mentioning.

The number of remnants found in the stream Bonin Potok is far too small to allow analysis. 


\section{Acknowledgements}

This paper is dedicated to Dr Nikola Pantić, who was first to describe paleoflora from these localities.

I would like to express my gratitude for help to Miloš Jović, Aleksandar Luković and Ranko Pejović, curators of the Natural History Museum in Belgrade.

\section{REFERENCES}

Djordjević Milutinović, D. (2010): An overview of Paleozoic and Mesozoic sites with macroflora in Serbia. - Bulletin of the Natural History Museum 3: 27-46.

Djordjević Milutinović, D. (2013): Taksonomska i paleoekološka analiza muzejske kolekcije „Karbonske biljke sa područja izmedju reka Mlava i Pek“ / Taxonomical and paleoecological analysis of Museum collection: "Carboniferous plants from area between the river Mlava and Pek". In: Museum documentation, Library of the Natural History Museum in Belgrade: 1-55. (elaborate) [In Serbian]

Pantić, N. (1951): Prilog poznavanju donjepermske flore Vrške Čuke (istočna Srbija) / The Supplement to the knowledge of the Lower Permian flora from Vrška Čuka (eastern Serbia). - Geološki anali Balkanskoga poluostrva 19: 119135. [In Serbian with English summary]

Pantić, N. (1952): Fosilna flora iz oblasti između Mlave i Peka (severoistočna Srbija) / La flore fossile de la region entre Mlava et Pek (la Serbie de nordest). - Geološki anali Balkanskoga poluostrva 20: 87-123. [In Serbian with French summary]

Pantić, N (1969): Granica karbon-perm u istočnoj Srbiji / Die Karbon-Perm Grenze in Osterserbien. - Zapisnici Srpskog geološkog društva za 1964, 1965, 1966 i 1967. godinu: 529-535. [In Serbian with German summary]

Stevanović, I. (1997): Karbonsko-permska flora sa područja izmedju reka Mlave i Peka i sa Vrške Čuke / Carboniferous-Permian flora from area between Mlava and Pek rivers and from Vrška Čuka mountain: 1-41. - Faculty of Mining and Geology, University of Belgrade / Library of the Natural History Museum in Belgrade. (graduate thesis, manuscr.) [In Serbian]

Veselinović, M., Divljan, M., Djordjević, M., Kalenić, M., Milošaković, R., Rajčević, D., Popović, R., Rudolf, Lj. (1975): Gornji karbon i perm / Upper Carboniferous and Permian. In: Osnovna geološka karta SFRJ 1:100 000 i Tumač za osnovnu geološku kartu, K 34-9, list Zaječar / Basic Geological Map FRY 1:100000 and Explanatory book for the Basic Geological Map, K 34-9, Sheet Zaječar: 20-22. - Savezni Geološki Zavod, Beograd. [In Serbian] 


\title{
ЗБИРКА КАРБОНСКИХ БИЉАКА СА ПОДРУЧЈА ВРШКЕ ЧУКЕ У ПРИРОДЊАЧКОМ МУЗЕЈУ У БЕОГРАДУ
}

\author{
ДЕСА ЂОРЂЕВИЋ МИЛУТИНОВИЋ
}

\section{Р Е 3 И М Е}

У Природњачком музеју у Београду налази се збирка добро очуваних примерака фосила карбонских биљака са подручја Вршке Чуке (источна Србија), са локалитета Узунов поток, Сурџијски поток и Бонин поток. Велики број примерака, добра очуваност фосилног материјала као и чињеница да је у Србији откривен мали број локалитета са карбонском флором највише су утицали на одлуку да се подаци о овој збирци публикују.

Основни проблем на самом почетку истраживања био је недостатак информација о историјату збирке: материјал није био инвентарисан, а такође није био познат ни укупан број примерака. Већина фосилног материјала налазила се у Палеоботаничкој збирци, међутим установљено је да се неколико кутија са фосилним биљкама Вршке Чуке налази и у другим геолошким збиркама као и у збиркама са изложбеним материјалом. После вишегодишњег истраживања прибављени су сви потребни подаци, збирка је комплетирана и инвентарисана.

У збирци су заступљене све групе биљака, карактеристичне за горњи карбон: голосеменице (Cordaites), семене папрати (Sphenopteris, Neuropteris, Odontopteris), дрволике папрати (Pecopteris, Asterotheca), дрволике пречице (Stigmaria, Lepidodendron) и каламити (Annularia, Calamites, Sphaenophyllum).

Треба напоменути да су дрволике пречице са сигурношћу утврђене само у Сурџијском потоку, што одговара мишљењу Н. Пантића (Pantić 1969) да је флора са овог локалитета нешто старија од флоре из Узуновог потока. Такође је разматрана могућност да у питању није разлика у стратиграфској припадности већ да су наведене флоре синхроне а да присуство односно недостатак представника Lepidodendrales једноставно одсликава еколошке разлике појединих станишта. Највише фосила припада роду Stigmaria.

Кордаити се у великом броју јављају на сва три локалитета. Листови су фрагментарни и нема ни једног целог листа. На појединим узорцима стена, листови се налазе у маси, један преко другог и због 
таквог начина фосилизације ове примерке није било могуће одредити до врсте те су они означени као Cordaites species plural, Cordaites spp. $\mathrm{C}$ друге стране, због лоше фосилизације, код неких примерака није било могуће утврдити којој врсти припадају и они су означени као Cordaites species, Cordaites $\mathrm{sp.}$

Дрволике папрати су такође бројне, а чињеница да нису констатоване у Бонином потоку пре се може приписати малом броју сакупљених примерака него стварној разлици у флористичком саставу у односу на друга два локалитета. Доминирају морфогенуси Pecopteris и Asterotheca, с обзиром да су то практично фертилне и стерилне пинуле истих папрати, као и да се на појединим примерцима на истој фронди могу видети и пинула са спорангијама и пинула без спорангија, оне су у раду разматране као једна група Pecopteris/Asterotheca.

Семених папрати има у великом броју и мада је за ову групу биљака неопходно урадити таксономску ревизију, са сигурношћу можемо рећи да су морфолошки разноврсне и да је заступљен већи број морфогенуса, што може значити да су заједно са кордаитима припадале климакс вегетацији. Углавном су констатоване појединачне пинуле, а веома ретко већи делови фронде. Такође је уочена мала заступљеност припадника Alethopteris и Linopteris, којих на другим горњекарбонским локалитетима као што је подручје између река Млава и Пек (стефански кат, источна Србија) има у великом броју (Pantić 1952, Đorđević Milutinović 2010, 2013).

Каламити су малобројни и нађени су углавном у Сурџијском потоку, чији палеофлористички састав (каламити, дрволике пречице, детритус, рибље крљушти), указује на мочварна станишта у близини обала. Од каламита углавном су нађена стабла и гране са листовима.

На основу презентованих података можемо закључити да палеофлора Узуновог и Сурџијског потока показује јасне разлике у свом саставу. У Узуновом потоку доминирају кордаити и папрати, док су семене папрати и каламити слабије заступљени а дрволике пречице недостају. Овакав састав палеофлоре указује на климакс заједницу која је насељавала шира подручја. За разлику од Узуновог, у Сурџијском потоку све класе су уједначено заступљене, укључујући и елементе мочварних станишта, каламите и дрволике пречице. Овакав палеофлористички састав указује на постојање азоналне приобалне вегетације.

За локалитет Бонин поток дат је само преглед фосилних биљака без разматрања заједнице, јер су налази малобројни да би се на основу њих могла извршити реконструкција заједнице. 



\section{Plate 1}

1. Callipteridium zeilleri, Surdžijski Potok, Inv. No. $1151_{1}$.

2. Pecopteris sp., Uzunov Potok, Inv. No. 1217.

3. Petrified wood, Uzunov Potok, Inv. No. 1280.

4. Cordaites palmaeformis, Uzunov Potok, Inv. No. $1045_{2}$.

5. Odontopteris minor, Uzunov Potok, Inv. No. $1286_{1}$.

6. Odontopteris minor, Uzunov Potok, Inv. No. 1287. 

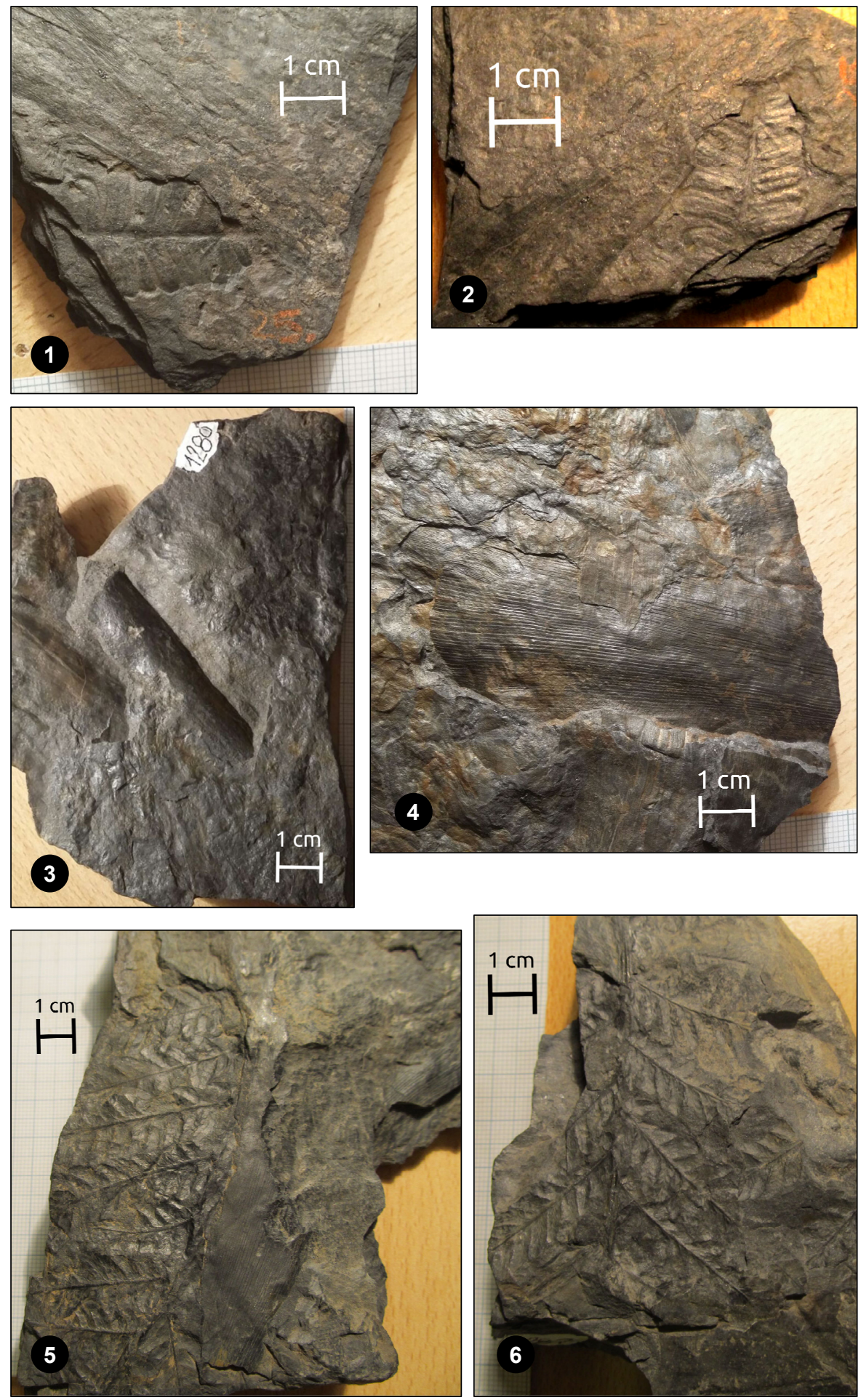


\section{Plate 2}

1. Stigmaria cf. ficoides, Surdžijski potok, Inv. No. 1201.

2. Cordaitanthus pseudofluitans vel Samaropsis sp., Uzunov Potok, Inv. No. 1291.

3, 4. Rhabdocarpus sp., compression and impression, Inv. No. 1204 a \& b.

5-7. Old notes (tags) found with fossils.

5. Transcript: "Uzunov Potok, 22-VII-49”.

6. Transcript: Sphenopteris ?; Annularia stellata, Potonie Element/200 pp.

7. Transcript: “Cordaitales, Sevard, Fossil Plants/III”. 

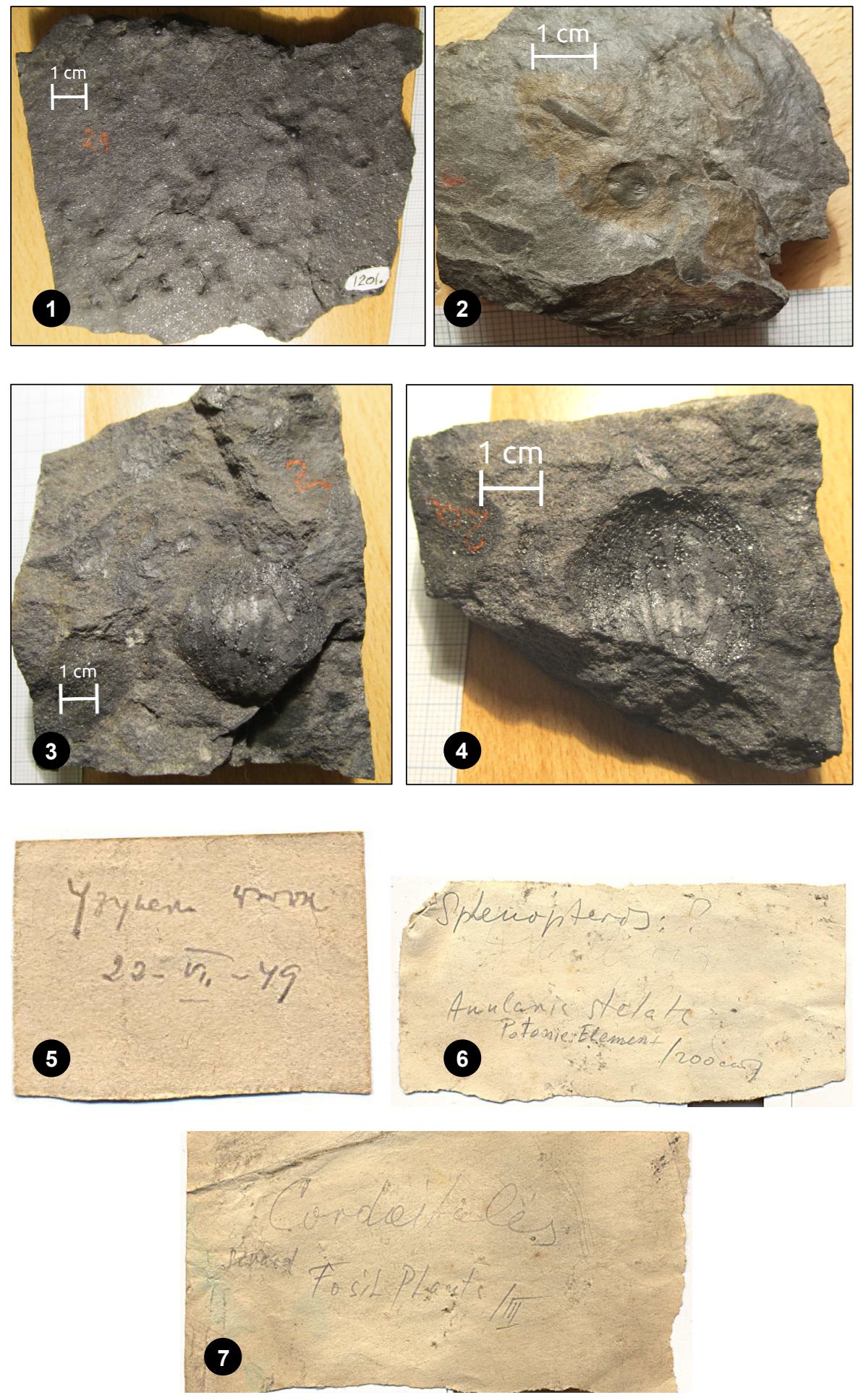